\title{
Tenuisentis niloticus (Neoechinorhychida: Tenuisentidae) as Indicator of BTEX and PAH Pollution in Epe Lagoon, Lagos, Nigeria
}

\author{
Bamidele Akinsanya $^{1}$, Isaac O Ayanda ${ }^{2, *}$, Benson Onwusa ${ }^{1}$ and Joseph K Saliu ${ }^{1}$ \\ ${ }^{1}$ Department of Zoology, University of Lagos, Lagos State, Nigeria \\ ${ }^{2}$ Department of Biological Sciences, Covenant University, Ota, Ogun State, Nigeria
}

\begin{abstract}
A B S T R A C T
The Lagos lagoon is continually being subjected to all forms of pollution. Human activities like industrialization, agriculture, and oil exploration are constantly threatening the health of this aquatic ecosystem. Polycyclic aromatic hydrocarbons (PAH) and mono-aromatic hydrocarbons-benzene, toluene, ethylbenzene and xylene (BTEX) are chemicals derived from fossil fuels that easily get into the aquatic environment. These chemicals were investigated in the fish parasite Tenuisentis niloticus, as a reflection of the extent to which these compounds are present in the lagoon. One hundred (100) samples of Heterotis niloticus were investigated for parasitic infection for a duration of six months, while the parasites encountered were used as sentinel organisms to check for the presence of PAH and BTEX. GC-MS was used to analyse for the presence of these chemicals, while parasite identification was done using conventional method. Only one parasite species, Teneuisentis niloticus, an acanthocephalan was recovered. There was $72 \%$ infection prevalence. The result also revealed that both BTEX and PAHs were accumulated in the body of the parasite. Two components of BTEX, (1,2-dichlorobenzene and 1,3-dichlorobenzene) and five PAH congeners-Acenaphthylene, Phenanthrene, benz(a)anthracene, benzo(a)pyrene and 7,12-dimethylbenz(a)anthracene were not detected in the parasite. Total BTEX and PAH concentrations in the parasite was $47.45 \pm 7.68$ and $135.12 \pm 2.547$, respectively. There are ecotoxic concerns in the surroundings of the lagoon and human activities that aid it should be checked.
\end{abstract}

Article Information
Received 10 July 2020
Revised 30 July 2020
Accepted 12 September 2020
Available online 14 May 2021
Authors' Contribution
BA conceived and designed the
experiments. IOA analyzed and
interpreted the data and wrote the
paper. BO performed the experiments.
JKS contributed reagents, materials
and edited the draft manuscript.
Key words
PAH, BTEX, Heterotis niloticus,
Teneuisentis niloticus, Parasite.

Article Information

Revised 30 July 2020

Accepted 12 September 2020

Available online 14 May 2021

Authors' Contribution

BA conceived and designed the experiments. IOA analyzed and interpreted the data and wrote the paper. BO performed the experiments. JKS contributed reagents, materials

PAH, BTEX, Heterotis nilotic

\section{INTRODUCTION}

$\mathrm{T}$ here is a need to continuously monitor the natural environment which has been subjected to progressive degradation due to biological and industrial pollution (Dzika and Wyzlic, 2010). To adequately assess and quantify the adverse effects of environmental stressors on the wellbeing of aquatic biota, organisms or communities whose important roles very closely correlate with certain environmental factors, so much that they can be useful indicators in the assessment of an area have enjoyed wide usage by researchers. Such organisms are defined as bioindicators (Markert et al., 2003).

The aquatic environment, being rich in both fauna and flora, having diverse niches and relatively stable, presents conducive conditions for the development, transmission and dispersal of parasites (Popiolek, 2001). In theory, aquatic ecosystems with zero pollution normally are richer in parasite communities (Marcogliese, 2005; Hudson et al., 2006).

Natural and anthropogenic activities and emissions

\footnotetext{
* Corresponding author: opeyemi.ayanda@covenantuniversity.edu.ng

0030-9923/2021/0004-1301 \$ 9.00/0

Copyright 2021 Zoological Society of Pakistan
}

remain the sources of PAHs in both terrestrial and aquatic environment (Obiakor et al., 2014). BTEX are common pollutants found in water in events of accidental oil spills and oil pipeline leakages, and also when contaminated industrial effluents are disposed of (Mazzeo et al., 2010; Costa et al., 2012).

BTEX and PAH are petroleum hydrocarbons reported to have adverse effects on aquatic biota (Akinsanya et al., 2020). Toxicological studies have reported that BTEX compounds are neuro- and hepato-toxins, with the ability to cause significant cognitive and behavioural effects when exposed to it (Santiago et al., 2014). They have also been known to cause malformation of chromosomal and/or genetic aberrations, making them genotoxic (Ekpenyong and Asuquo, 2017). PAHs on the other hand are carcinogenic (Neff, 2003), induce oxidative stress (Dizdaroglu et al., 2002), affects the immune system (Holladay et al., 1998) and disrupt endocrine regulation and development (Gozgit et al., 2004; Navas and Segner, 2000; Rhodes et al., 2005).

Organisms that are able to concentrate certain substances in the tissues of their body in amounts that are higher than those in their surrounding environment are described as accumulation indicators (Beeby, 2001). They are able to provide important information on the 
volume of chemicals in their habitats and by extension provide knowledge about the biological availability of target substances. Parasites are being used as one of such organisms.

Parasitic infection in aquatic organisms is not an uncommon occurrence. Intensive research into the field of environmental parasitology has been on the rise, and it has been reported that parasites can be useful accumulation bioindicators (Sures, 2003, 2004; Vidal-Martínez et al., 2006; Yen et al., 2014).

There have been recent reports (Akinsanya et al., 2019a, b) of pollution (BTEX, heavy metals and OCPs) from the Lagos lagoon. Furthermore, reports of the use of parasites as sentinel organisms from natural waters exists. Oncomegas wageneri, a cestode was used to monitor PAHs in the fish Cylopsetta chittendeni in Mexico. Aspidogastrea africanus was used to monitor PAH from the Lagos lagoon using the fish Chrysichthys nigrodigitatus (Akinsanya et $a l ., 2020)$. BTEX was also reported to be monitored using the parasite Wenyonia acuminate recovered from the fish Synodontis clarias (Akinsanya et al., 2019a).

The Lagos lagoon is a coastal water aquatic ecosystems at the highest risk of pollution from human activities and subsequently, environmental degradation due to their vulnerability. The area is a rural settlement, most human population being concentrated along the lagoon bank. Human activities like agriculture, sand mining, fishing and movement of people and goods occur. Wastes from a number of industries that are located in the state are disposed of in these water bodies (Anetekhai et al., 2007). Hydrophytes, occurring around the edges of the lagoon, shrubs and palm trees scattered around the villages surrounding it are some of the dominant vegetation that characterize the Lagos lagoon. Hence this study was designed with the aim of determining the prevalence of parasitic helminth infections in Heterotis niloticus, and analysing the parasites for PAHs and BTEX.

\section{MATERIALS AND METHODS}

\section{Study area}

Epe, Lekki, Lagos and Ologe lagoons are the four major lagoons in the state. The Lagoon's coordinates are between latitudes $6^{\circ} 29 \mathrm{~N}$ and $6^{\circ} 38 \mathrm{~N}$; and longitudes $3^{\circ} 30$ $\mathrm{E}$ and $4^{\circ} 05 \mathrm{E}$ (Agboola and Anetekhai, 2008). A large part of the lagoon has maximum depth of about $6.0 \mathrm{~m}$ (Fig. 1).

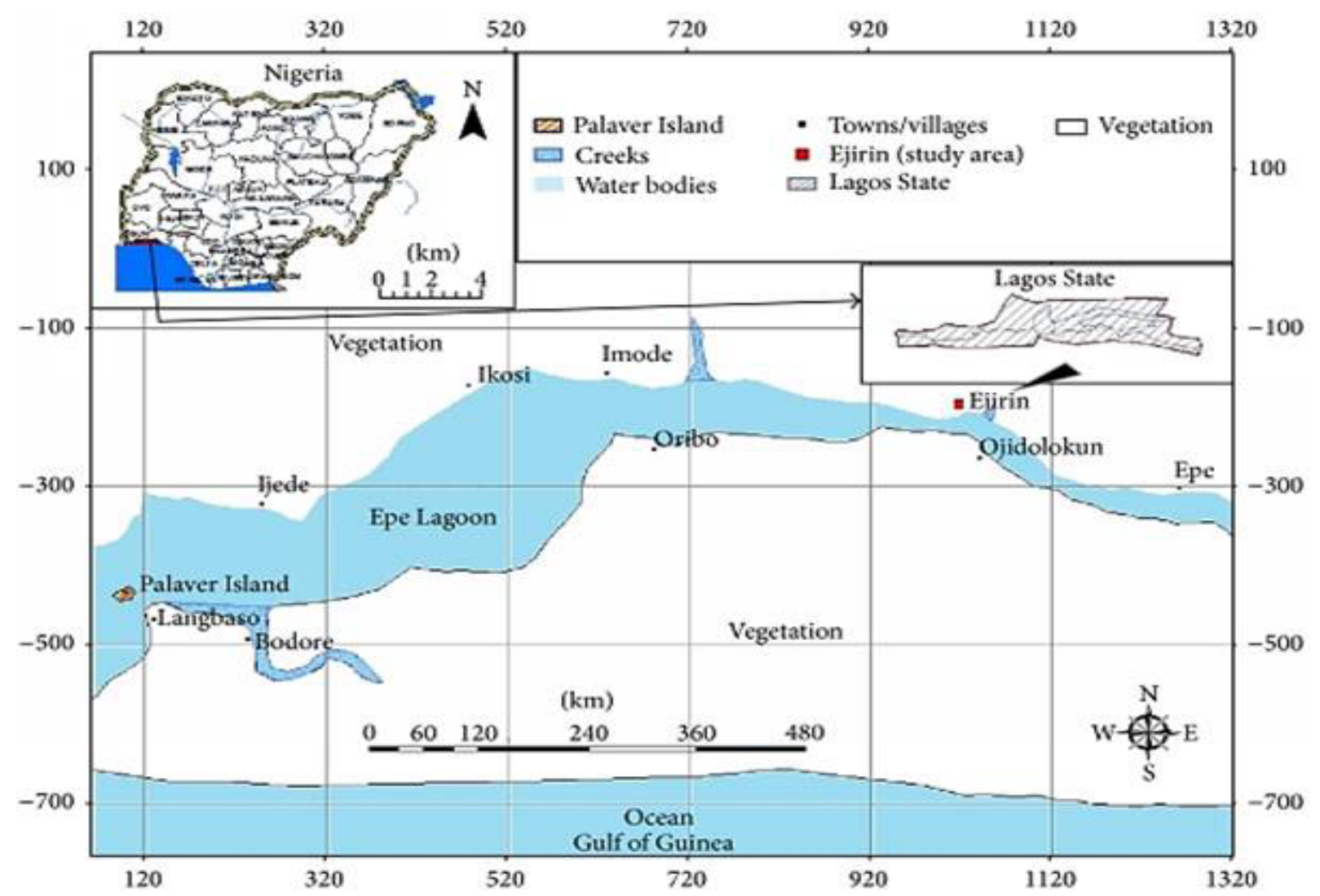

Fig. 1. Map of the Epe Axis of Lekki Lagoon. 


\section{Fish collection and examination for parasites}

One hundred (100) samples of Heterotis niloticus, 90 males and 10 females, were obtained between April and September 2018 from the lagoon with the assistance of fishermen using appropriate fishing gears. The fish were taken on ice to the laboratory and examined immediately for parasites. Morphometric measurements of the fish were taken.

After dissection, fish gut was excised. To recover the parasites, the alimentary canal was cut into sections and placed in petri dishes containing physiological saline. Furthermore, the intestines were longitudinally cut open to allow the parasites to emerge easily from the gut. The intestines and liver of the fish was also harvested and kept in teflon lined caped vial and refrigerated before further analysis for the presence of hydrocarbon. Thereafter, fixation of the guts that were infected with parasites was done for $7 \mathrm{~h}$ in Bouins fluid and were later preserved in $10 \%$ phosphate buffered formulation. The number of parasites observed was recorded and fixed in $70 \%$ alcohol. For identification, parasites were sent out to the British Natural History Museum, United Kingdom.

\section{Extraction and purification of BTEX and PAHs in parasites}

The method used was the KOH Refluxing/Vortex Extraction EPA Method 3611C where the parasite was macerated, homogenized and the homogenized tissue placed in a $50 \mathrm{~mL}$ centrifuge tube. $15 \mathrm{~mL}$ of $6 \mathrm{~N} \mathrm{KOH}$ was added to it, and transferred into sealed tubes and incubated for $18 \mathrm{~h}$ in a $35^{\circ} \mathrm{C}$ water bath, while shaking vigorously for 30 second for every $1 / 2$ hour for the first $4 \mathrm{~h}$. Thereafter, $15 \mathrm{~mL}$ of methylene was added to the centrifuge tube and centrifuged at $2000 \mathrm{rpm}$ for $5 \mathrm{~min}$ to facilitate phase separation. The upper aliquot layer was removed using Pasteur pipettes into a $250 \mathrm{~mL}$ round-bottom flask. Sample extracts was concentrated to about $5-10 \mathrm{~mL}$ by rotary evaporator prior to fractionation for aliphatic hydrocarbons and PAHs using alumina gel column fractionation and clean up procedure. To prepare a column, $11 \pm 0.01 \mathrm{~g}$ of activated silica/alumina gel was weighed into a beaker, hexane/methylene chloride was added to form a slurry that is poured into the chromatographic column with a based glass wool, rinsing all the silica/alumina gel into the column with the solvent used. Hexane $(10 \mathrm{~mL})$ was used to condition the column, and elution was done at a rate of $1 \mathrm{drop} / \mathrm{sec}$. The elution was stopped when the solvent reaches the top of the column after which the eluate was concentrated to $2 \mathrm{ml}$ using rotary evaporator, and about $1 \mathrm{~g}$ sodium sulphate was added to remove any remaining water in the extract which was stored in a $2 \mathrm{ml} \mathrm{GC}$ vial below $4^{\circ} \mathrm{C}$ prior to $\mathrm{GC}$ analysis.

\section{Chemical analysis}

Agilent 7890B gas chromatograph coupled to flame ionization detector (FID) was used for PAH determination as described by Yao et al. (2013). To separate the compounds, HP-5 capillary column coated with 5\% phenyl methyl siloxane was used as the stationary phase. Injection was done using $1 \mu \mathrm{L}$ of the samples, injected at $300^{\circ} \mathrm{C}, 13.74$ psi temperature and pressure respectively

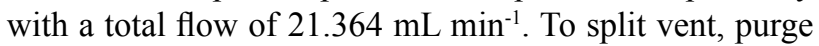
flow was set for $0.75 \mathrm{~min}$ at $15 \mathrm{mLmin}^{-1}$. Oven was programmed at $40^{\circ} \mathrm{C}$ for a min, later at $12^{\circ} \mathrm{C} \mathrm{min}-1$ and finally set to $300^{\circ} \mathrm{C}$ for $10 \mathrm{~min}$. The temperature of the FID was $300^{\circ} \mathrm{C}$ with hydrogen: Air flow at $30 \mathrm{~mL} \mathrm{~min}^{-1}$ : $300 \mathrm{mLmin}^{-1}$ while the makeup gas, nitrogen was set at a flow rate of $22 \mathrm{mLmin}^{-1}$. Thereafter, the samples were analyzed and the concentration of the corresponding PAHs was obtained.

BTEX was analysed using the EPA method $8260 \mathrm{~B}$ Agilent 7890B gas chromatograph coupled to a mass spectrophotometer (GC-MS). The stationary phase of separation of the compounds used was a DB-5 capillary column coated with $95 \%$ dimethyl - 5\% diphenyl polysiloxane $(30 \mathrm{~m}$ length $\mathrm{x} 0.32 \mathrm{~mm}$ diameter $\times 1.0$ $\mu \mathrm{m}$ film thickness) (Agilent Technologies). $1 \mu \mathrm{L}$ of the samples was injected in split mode with split ratio 100:1 at an injection temperature of $125^{\circ} \mathrm{C}$, oven was initially programmed at $35^{\circ} \mathrm{C}$ (held for $2 \mathrm{~min}$ ) then ramped at $4^{\circ} \mathrm{C} /$ min to $50^{\circ} \mathrm{C}$ and then $10^{\circ} \mathrm{C} / \mathrm{min}$ to $220^{\circ} \mathrm{C}$, helium flow rate was set at $1.5 \mathrm{~mL} \mathrm{~min}^{-1}$, while the mass range was set at $35-260$ amu and scan time at $0.6 * 2 \mathrm{sec} / \mathrm{scan}$.

\section{Statistical analysis}

Result was presented as mean and standard deviation. Comparison of differences in the activities of enzymes between parasitized and non-parasitized fishes was done using Student's t-test and significance was considered at $5 \%(\mathrm{p}<0.05)$ level.

\section{RESULTS}

\section{Prevalence of intestinal helminths in Heterotis niloticus}

A total of 100 fish specimen of $H$. niloticus were sampled for presence of parasites. Only one parasite species - T. niloticus was identified in all the infected fishes. The number of fish infected, prevalence of infection and the number of worms recovered are presented in Table 1. 36 fishes of the total sample are infected with parasite. It can be deduced from the result, an average prevalence parasite infestation of $72 \%$, with, a mean intensity of 55.56 , median intensity of 55.0 and a total worm load of 301 . $100 \%$ infection prevalence was observed in the standard length group $55-59.9 \mathrm{~cm}$ and $75-79.9 \mathrm{~cm}$. This may be 
attributable to the random selection, while the 45-49.9 $\mathrm{cm}$ and $50-54.9 \mathrm{~cm}$ had $83 \%$ and $62 \%$ prevalence rates, respectively. Worm load observed was highest in the 60$64.9 \mathrm{~cm}$ length group of 93 worms counted, while the least group with worm load was the 75-79.9 $\mathrm{cm}$ length group.

\section{BTEX in parasite}

The values for the individual component of BTEX in the parasite $T$. niloticus, fish liver and intestine are presented in Figure 2. Total BTEX concentration in parasite was found to be $47.45 \pm 7.68 \mu \mathrm{g} / \mathrm{g}$. Benzene was observed to have the highest value, followed by toluene and $\mathrm{m}+\mathrm{p}$ xylene. 1,4-dichlorobenzene had the least value while 1,2-dichlorobenzene and 1,3-dichlorobenzene were not detected in the parasite.

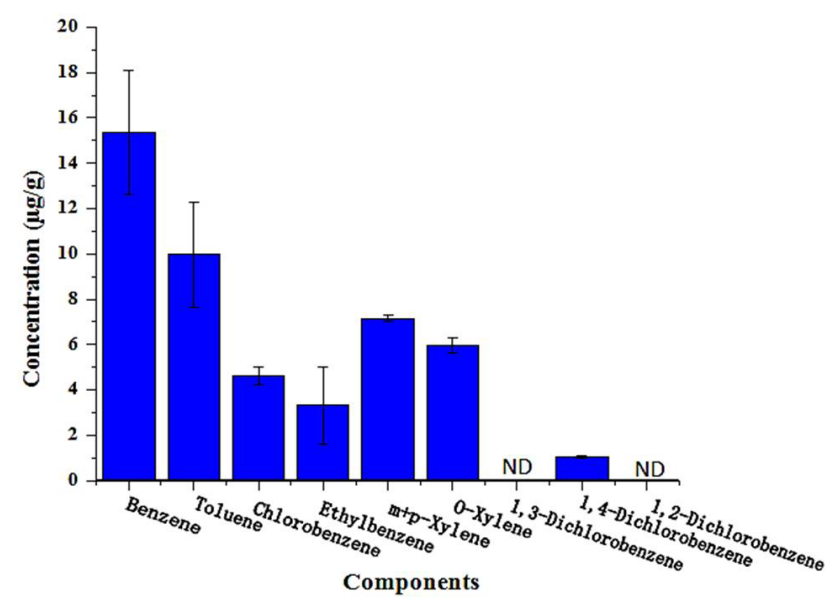

Fig. 2. Mean concentration of BTEX $(\mu \mathrm{g} / \mathrm{g})$ in parasite.

Table I.- Prevalence of helminthic infection in Heterotis niloticus.

\begin{tabular}{lcccc}
\hline $\begin{array}{l}\text { Standard } \\
\text { length class }\end{array}$ & $\begin{array}{c}\text { No. of } \\
\text { fish }\end{array}$ & $\begin{array}{c}\text { No. of } \\
\text { infected fish }\end{array}$ & $\begin{array}{c}\text { Prevalence } \\
\text { (\%) }\end{array}$ & $\begin{array}{c}\text { Worm } \\
\text { load }\end{array}$ \\
\hline $40-49.9 \mathrm{~cm}$ & 30 & 20 & 67 & 110 \\
$50-59.9 \mathrm{~cm}$ & 26 & 22 & 85 & 66 \\
$60-69.9 \mathrm{~cm}$ & 34 & 20 & 59 & 101 \\
$70-80 \mathrm{~cm}$ & 10 & 8 & 80 & 24 \\
Sum & 100 & 70 & 70 & 301 \\
\hline
\end{tabular}

\section{PAH in parasite}

The different PAH congeners and their mean values as measured in the parasite Teneuisentis niloticus are presented in Figure 3. Benzo(e)pyrene has the highest concentration of all the PAHs in the parasite, followed by fluoranthene. The following components of PAH, naphthalene, acenaphthylene, phenanthrene, benz(a) anthracene, benzo(a)pyrene and 7,12-dimethylbenz(a) anthracene were not detected in the parasite. Benzo(c) phenanthrene had the lowest concentration of all the PAH components. The sum of all the PAH congeners is also presented in Table I.

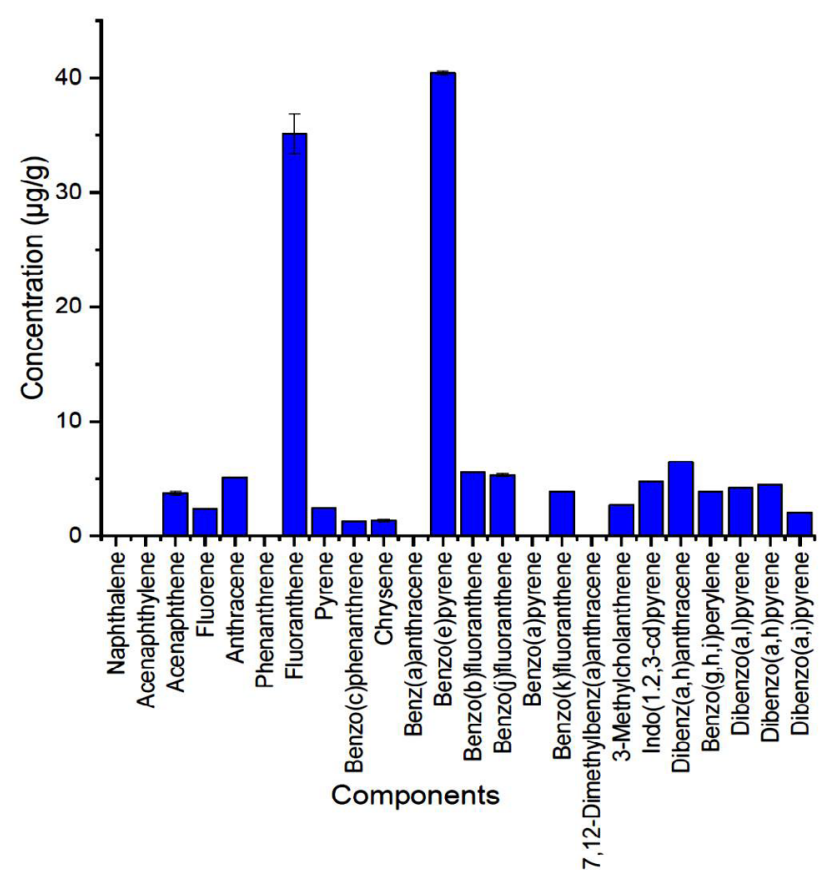

Fig. 3. Mean concentration of PAH $(\mu \mathrm{g} / \mathrm{g})$ in parasite.

\section{DISCUSSION}

The presence of parasites in fish may not be unconnected with the pollution state of the particular water body. The threats posed by parasites to fish cannot be overemphasized. Detrimental behavioural responses, reproductive damage, altered growth, mechanical and physiological damage, and inability of parasitized organ to function properly are some health effects of parasitism in fish (Iwanowicz, 2011). Aesthetic value of fish is also greatly reduced. In the present study, the intestinal parasite found in $H$. niloticus was an acanthocephalan- $T$. niloticus, a thorny-headed worm. Previously, researchers have reported the presence of acanthocephalans from freshwater fish (Oniye et al., 2004; Ayanda, 2008). As reported by Akinsanya and Otubanjo (2006), it is possible that differences in geographic factors do not greatly affect the kinds of parasites that infect fish. The length group 30-39.9 cm recorded zero prevalence of infection. It has been reported (Roberts, 1978), that smaller fishes provide less surface area for infection as compared to bigger fishes. Fishes between the length category 50-64.9 $\mathrm{cm}$ had the highest parasite load. As reported by Khalil 
(1969), infection with parasites is proportional to fish length. Bigger fishes probably provided larger surface area for parasite habitation and feeding. However, the random selection of fishes could also have played a role in this. There is a high overall infection prevalence rate of $72 \%$. This may be a reflection of the pollution status of the Lagos lagoon. Human activities in the form of indiscriminate discharge of wastes and even transport activities may have contaminated the water. This would probably have led to increased contact between parasite and host as fishes desperately search for food. T. niloticus was the only parasite species observed to infect $H$. niloticus in this study. It may be a reflection of the abundance of the intermediate host of this parasite in the Lagos lagoon, making it easy for them to easily get into their definitive host.

BTEX and PAH have been reported to be present in parasite tissues in this study. This can be seen as an indication of the prevailing conditions in the body of the fish host, $H$. niloticus and also the habitat of the fish. The sources of introduction of these chemicals into the lagoon are not far-fetched. Lagos is a heavily populated and industrial area. Spillage from oil rig areas, as well as maritime transport are two important processes that have been implicated in water pollution by these chemicals. Additionally, atmospheric deposition into water can also be responsible (Obiakor et al., 2014). As these chemicals are soluble in water, they can spread very rapidly, hence taken up by aquatic organisms.

Some BTEX and PAH congeners were not detected at all in the parasite, they may or may not be present in water and fish host. Of those that were detected, some were high while others were low. Important processes by which BTEX and PAHs in aquatic ecosystems degrade includes chemical oxidation, photooxidation and biological transformation by organisms. This process occurs at a very slow rate in aquatic environments when compared with the time it takes to degrade in the atmosphere. It has been said that the cycling of PAHs in aquatic environments, is poorly understood, as it is for other ecological systems (Neff, 1979).

It has been reported that parasites have ability to accumulate pollutants at levels higher than those found in their immediate surroundings, hence making them effective as sentinel organisms in environmental monitoring studies (Nachev and Sures, 2015). Sures (2001, 2003) reported that parasites show exceptional properties with regards to accumulating substances which have a high affinity for water, hence, making them even better accumulation indicators than conventional bioindicator organisms. Studies on the marine fish-acanthocephalan system (Nothotenia coriiceps-Aspersentis megarhynchus) have shown that the parasite concentrated higher amount of pollutants in its body than the levels found in common accumulation indicators like the mussel, Leternula elliptica (Sures and Reimann, 2003). Similarly, more detailed studies on the freshwater fish-acanthocephalan systems further shows that acanthocephalans can be regarded as accumulation indicators since they are able to accumulate pollutants better than other parasites and other indicator organisms (Sures et al., 1994, 1999; Sures, 2004). The parasite identified in the present study is also an acanthocephalan, further buttressing these previous reports of them being very good indicator organisms.

Interestingly, Akinsanya et al. (2019) in a similar study reported that the parasite Wenyonia acuminata, infecting Synodontis clarias in the same study area did not bioaccumulate BTEX from fish. This may be due to differences in bioaccumulation factors of chemicals in different parasites species. Fish parasitism is not a desirable condition, be it in fish farms or in the wild; however, that parasites are able accumulate pollutants from fish when parasitizing them is a good phenomenon. Considering the health implications to man of the buildup of BTEX and PAH in fish, the ability for the parasites to accumulate these chemicals from fish body creates a situation whereby the risk to man when consuming these organisms is greatly reduced.

In conclusion, over the years, established sentinel organisms have enjoyed wide patronage in environmental bio monitoring and impact assessment studies. Further studies investigating the use of parasites as sentinel organisms not only in fish but in other aquatic organisms is encouraged as this will provide more information on pollutant accumulation. This undoubtedly will give a better understanding of the level of pollution in our aquatic ecosystems.

\section{Statement of conflict of interest}

The authors have declared no conflict of interests.

\section{REFERENCES}

Agboola, J.I. and Anetekhai, M.A., 2008. Lengthweight relationships of some fresh and brackish water fishes in Badagry creek, Nigeria. J. appl. Ichthyol., 24: 623-625. https://doi.org/10.1111/ j.1439-0426.2008.01079.x

Akinsanya, B. and Otubanjo, O.A., 2006. Helminth Parasites of Clarias gariepinus (Clariidae) in Lekki Lagoon, Lagos, Nigeria. Rev. Biol. Trop., 54: 9399. https://doi.org/10.15517/rbt.v54i1.14003

Akinsanya, B., Isibor, P.O., Kuton, M.P., Saliu, J.K. and Dada, E.O., 2019a. Aspidogastrea africanus infections, comparative assessment of 
BTEX and heavy metals bioaccumulation, and histopathological alterations as biomarker response in Chrysichthys nigrodigitatus (Lacépède, 1803) of Lekki Lagoon, Nigeria. Sci. Afr., 3: e00060. https:// doi.org/10.1016/j.sciaf.2019.e00060

Akinsanya, B., Isibor, P.O., Kuton, M.P., Dada, E.O. and Saliu, J.K., 2019b. Comparative partition coefficients of BTEX and OCPs between host Synodontis clarias and parasite Wenyonia acuminata. J. Basic appl. Zool., 80: 38. https://doi. org/10.1186/s41936-019-0090-6

Akinsanya, B., Isibor, P.O., Kuton, M.P., Mulikat, K. and Saliu, J.K., 2020. Parasite prevalence and bioaccumulation of polycyclic aromatic hydrocarbons as stressors in the silver catfish, Chrysichthys nigrodigitatus (Siluriformes: Claroteidae). Sci. Afr., 7: e00225. https://doi. org/10.1016/j.sciaf.2019.e00225

Anetekhai, M.A., Akin-Oriola, G.A., Aderinola, O.J. and Akintola, S.L., 2007. Trace metal concentration in Macrobrachium vollenhovenii from Ologe Lagoon, Lagos, Nigeria. J. Afrotrop. Zool., 2007(Sp. Issue): 25-29.

Ayanda, O.I., 2008. Comparison of parasitic helminth infection between the different age groups of Clarias gariepinus from Asa dam Ilorin, northcentral Nigeria. Afr. J. environ. Sci. Technol., 2: 404-406.

Beeby, A., 2001. What do sentinels stand for? Environ. Pollut., 112: 285-98. https://doi.org/10.1016/ S0269-7491(00)00038-5

Costa, A.S., Romăo, L.P.C., Araujo, B.R., Lucas, S.C.O., Maciel, S.T.A., Wisniewski, A., Alexandre, M.D.R., 2012. Environmental strategies to remove volatile aromatic fractions (BTEX) from petroleum industry wastewater using biomass. Bioresour. Technol., 105: 31-39. https://doi.org/10.1016/j. biortech.2011.11.096

Dizdaroglu, M., Jaruga, P., Birincioglu, M. and Rodriguez, H., 2002. Free radical-induced damage to DNA: Mechanisms and measurement. Free Rad. Biol. Med., 32: 1102-1115. https://doi.org/10.1016/ S0891-5849(02)00826-2

Dzika, E. and Wyzlic, I., 2010. Fish parasites as quality indicators of aquatic environment. Zool. Pol., 5455: 59-65. https://doi.org/10.2478/v10049-0100006-y

Ekpenyong, C.E. and Asuquo, A.E., 2017. Recent advances in the occupational and environmental health hazards of workers exposed to gasoline compounds. Int. J. Occup. Med. environ. Hlth., 30: 1-26. https://doi.org/10.13075/ijomeh.1896.00800
Gozgit, J.M., Nestor, K.M., Fasco, M.J., Pentecost, B.T. and Arcaro, K.F., 2004. Differential action of polycyclic aromatic hydrocarbons on endogenous estrogen-responsive genes and on a transfected estrogen-responsive reporter in MCF-7 cells. Toxicol. appl. Pharmacol., 196: 58-67. https://doi. org/10.1016/j.taap.2003.12.003

Holladay, S.D., Smith, S.A., Besteman, E.G., Deyab, A.S.M.I., Gogal, R.M., Hrubec, T., Robertson, J.L. and Ahmed, S.A., 1998. Benzo[a]pyreneinduced hypocellularity of the pronephros in tilapia (Oreochromis niloticus) is accompanied by alterations in stromal and parenchymal cells and by enhanced immune cell apoptosis. Vet. Immunol. Immunopathol., 64: 69-82. https://doi.org/10.1016/ S0165-2427(98)00116-0

Hudson, P., Dobson, A.P. and Lafferty, K.D., 2006. Is a healthy ecosystem one that is rich in parasites? Trends Ecol. Evolut., 21: 381-385. https://doi. org/10.1016/j.tree.2006.04.007

Iwanowicz, D.D., 2011. Overview on the effects of parasites on fish health. Proceedings of the Third Bilateral Conference between Russia and the United States, 12-20 July, 2009, held in Shepherdstown, West Virginia, pp. 176-184.

Khalil, L.F., 1969. Larval nematodes in the herring (Clupea harengus) from British coastal waters and adjacent territories. J. mar. Biol. Assoc. UK, 49: 641659. https://doi.org/10.1017/S002531540003719X

Marcogliese, D.J., 2005. Parasites of the superorganism: Are they indicators of eco-system health? Int. J. Parasitol., 35: 705-716. https://doi.org/10.1016/j. ijpara.2005.01.015

Markert, B., Breure, A. and Zechmeister H., 2003. Bioindicators and biomonitors. Principles, concepts and applications. Elsevier, Amsterdam, Netherlands.

Mazzeo, D.E.C., Levy, C.E., De Angelis, D.D.F. and Marinmorales, M.A., 2010. BTEX biodegradation by bacteria from effluents of petroleum refinery. Sci. Total Environ., 408: 4334-4340. https://doi. org/10.1016/j.scitotenv.2010.07.004

Nachev, M. and Sures, B., 2015. Environmental parasitology: Parasites as accumulation bioindicators in the marine environment. $J$. Sea Res., 113: 45-50. https://doi.org/10.1016/j. seares.2015.06.005

Navas, J.M. and Segner, H., 2000. Antiestrogenicity of $\beta$-naphthoflavone and PAHs in cultured rainbow trout hepatocytes: Evidence for a role of the arylhydrocarbon receptor. Aquat. Toxicol., 51: 79-92. https://doi.org/10.1016/S0166- 
445X(00)00100-4

Neff, J.M., 1979. Polycyclic aromatic hydrocarbons in the aquatic environment. Sources, fates and biological effects. Allied Science Publishers, Essex, pp. 262.

Neff, J.M., 2003. Polycyclic aromatic hydrocarbons in the ocean. In: Bioaccumulation in marine organisms-Effect of contaminants from oil well produced water. Elsevier, Amsterdam, pp. 241318. https://doi.org/10.1016/B978-0080437163/50016-6

Obiakor, M.O., Okonkwo, J.C., Ezeonyejiaku, C.D. and Okonkwo, C.N., 2014. Polycyclic aromatic hydrocarbons (PAHs) in freshwater media: Factorial effects and human dietary exposure risk assessment. Res. Environ., 4: 247-259. https://doi. org/10.5455/jeos.20150105105524

Oniye, S.J., Adebote, D.A. and Ayanda, O.I., 2004. Helminth parasites of Clarias gariepinus in Zaria, Nigeria. J. aquat. Sci., 19: 71-76. https://doi. org/10.4314/jas.v19i2.20027

Popiolek, M., 2001. Helmintofauna ryb wybranych rzek i ciekÛw Dolnego ål $\pi$ ska na tle stopnia czystoúci wÛd. Uniwersytet Wroc $\geq$ awski, Wydzia $\geq$ Nauk Przyrodniczych, (praca doktorska).

Rhodes, S., Farwell, A., Hewitt, L.M., MacKinnon, M. and Dixon, D.G., 2005. The effects of dimethylated and alkylated polycyclic aromatic hydrocarbons on the embryonic development of the Japanese medaka. Ecotoxicol. environ. Safety, 60: 247-258. https://doi.org/10.1016/j.ecoenv.2004.08.002

Roberts, R.J., 1978. Fish pathology. Bailliere, London, pp. 318.

Santiago, F., Alves, G., Otero, U., Tabalipa, M., Scherrer, L., Kosyakova, N., Ornellas, M. and Liehr, T., 2014. Monitoring of gas station attendants exposure to benzene, toluene, xylene (BTX) using three-color chromosome painting. Mol. Cytogen., 7: 1. https:// doi.org/10.1186/1755-8166-7-15

Soler-Jiménez, L.C., Hernández-Núñez, E., VelázquezAbunader, I., Centeno-Chalé, A. and VidalMartínez, V.M., 2020. Polycyclic aromatic hydrocarbons in the cestode Oncomegas wageneri parasite of Mexican flounder Cyclopsetta chittendeni. Parasitol. Res., 119: 903-913. https:// doi.org/10.1007/s00436-019-06597-z

Sures, B., Taraschewski, H. and Jackwerth, E., 1994. Lead content of Paratenuisentis ambiguous (Acanthocephala), Anguillicola crassus
(Nematodes) and their host Anguilla anguilla. Dis. aquat. Org., 19: 105-107. https://doi.org/10.3354/ dao019105

Sures, B., Steiner, W., Rydlo, M. and Taraschewski, H., 1999. Concentrations of 17 elements in the zebra mussel (Dreissena polymorpha), in different tissues of perch (Perca fluviatilis), and in perch intestinal parasites (Acanthocephalus lucii) from the subalpin lake Mondsee (Austria). Environ. Toxicol. Chem., 18: 2574-2579. https://doi.org/10.1002/ etc. 5620181126

Sures, B., 2001. The use of parasites as bioindicators of heavy metals in aquatic ecosystems: A review. Aquat. Ecol., 35: 245-255. https://doi. org/10.1023/A:1011422310314

Sures, B., 2003. Accumulation of heavy metals by intestinal helminths in fish: an overview and perspective. Parasitology, 126: 53-60. https://doi. org/10.1017/S003118200300372X

Sures, B. and Reimann, N., 2003. Analysis of trace metals in the Antarctic host-parasite system Notothenia coriiceps and Aspersentis megarhynchus (Acanthocephala) caught at King George Island, South Shetland Islands. Polar Biol., 26: 680-686. https://doi.org/10.1007/s00300-003-0538-4

Sures, B., 2004. Fish acanthocephalans of genus Pomphorhynchus sp. as globally applicable bioindicators for metal pollution in the aquatic environment? Wien. Klin. Wochenschr., 116(Suppl 4): 19-23.

Vidal-Martínez, V.M., AguirreMacerdo, M.L., Del Rio-Rordrígez, R., Gold-Bouchot, G., Rendónvon Osten, J. and Mirande-Rosas, G.A., 2006. The pink shrimp Farfantepenaeus duorarum, its symbionts and helminthes as bioindicators of chemical pollution in Campeche Sound, Mexico. $J$. Helminthol., 80: 159-174. https://doi.org/10.1079/ JOH2006358

Yao, T., Hea, C., Zhangb, P., Gaob, H. and Zhou, C., 2013. Distribution and sources of polychlorinated biphenyls (PCBs) and organochlorine pesticides (OCPs) in surface waters of Jinzhou Bay in China. Proc. environ. Sci., 18: 317-322. https://doi. org/10.1016/j.proenv.2013.04.041

Yen, L.T.T., Rijsdijk, L., Sures, B. and Hendricks, A.J., 2014. Accumulation of persistent organic pollutants in parasites. Chemosphere, 108: 145-151. https:// doi.org/10.1016/j.chemosphere.2014.01.036 